\title{
The relationship between emotional intelligence and leadership styles in the South African petrochemical industry
}

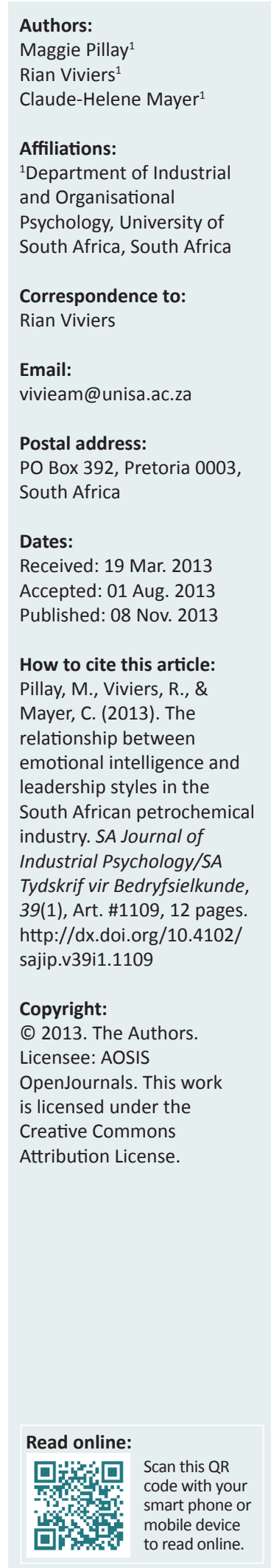

Orientation: Although research on emotional intelligence in the context of leadership has remained a recurrent area of interest in theory and practice during the past decade, ongoing debate continues regarding the contribution of emotional intelligence to the understanding of leadership.

Research purpose: The aim of this study was to determine the relationship between selfreported emotional intelligence and leadership styles in a South African context and to determine whether emotional intelligence can predict an effective leadership style.

Motivation for the study: Research is needed in order to determine a more detailed relationship between emotional intelligence and leadership in the dynamic and globalising South African petrochemical context.

Research design, approach and method: The study was conducted in terms of a positivist paradigm, using quantitative research instruments. Leaders $(N=161)$ were selected from a business unit in a South African petrochemical organisation. Self-reports from the emotional quotient inventory and the Multifactor Leadership Questionnaire (MLQ Form 5X, Version 2009) were analysed. Correlation analyses indicated statistically-significant relationships between emotional intelligence and transformational and laissez-faire leadership.

Main findings: Findings indicated positive correlations between self-reported emotional intelligence (specifically adaptability) and transformational leadership. Negative correlations were obtained between emotional intelligence (specifically intrapersonal skills) and laissez-faire leadership. The research also showed differences between specific demographic variables.

Practical/managerial implications: This study provides valuable significance for organisations' endeavours in improving, training and identifying alternative selection and assessment procedures for evaluating leaders' strengths.

Contribution/value-add: This research contributes to the South African research on emotional intelligence and leadership styles and thereby adds context-specific value to the topic within a specific cultural and organisational context.

\section{Introduction}

Research on emotional intelligence (EI) in the context of leadership has remained a recurrent area of interest for more than 10 years (Cacioppe, 1998; Cavazotte, Moreno \& Hickmann, 2012). This is reflected, for example, in studies of leaders' emotional expression in the workplace (Bono \& Ilies, 2006; Hur, Van den Berg \& Wilderom, 2011) as well as in the way leadership styles impact on the emotional states of employees, enhancing organisational commitment, proactive behaviour and job performance (Riggio \& Reichard, 2008).

Nevertheless, ongoing debate continues regarding the contribution of EI to our understanding of leadership (Antonakis, Ashkanasy \& Dasborough, 2009; Landy, 2005; Locke, 2005). In this study, leadership is described in terms of the transformational, transactional and laissez-faire leadership styles (Bass \& Avolio, 1994). Transformational leaders, in contrast to transactional and laissez-faire leaders, are seen as agents of social and organisational change and regarded as effective (Bass, 1985; Cavazotte et al., 2012). They are described as being models for conduct and as being able to inspire a new and stimulating vision in their followers. In doing so, they elevate morale, inspire followers and motivate them toward greater achievements or conquests (Bass, 1985). Furthermore, meta-analytic reviews have validated positive connections between transformational leadership of superiors and performance of subordinates (Harms \& Credé, 2010; Lowe, Kroeck \& Sivasubramanian, 1996). Subsequently, various studies have found a relationship 
between transformational leadership and the efficacy of organisations (Avolio, 1999; Chuang, Judge \& Liaw, 2012).

Associated studies examining EI within a project management context have found it to be a significant area of individual difference associated with effective leadership and, more specifically, transformational leadership (Clarke, 2010). Others have noted the disappointing results of intelligence and personality models in the prediction of exceptional leadership and have argued that EI may represent an elusive ' $X$ ' factor for predicting transformational leadership (Brown \& Moshavi, 2005).

Consequently, research is needed so as to determine whether this relationship exists within the South African context, in particular in the petrochemical industry. Limited research exists regarding EI and leadership styles, particularly transformational leadership, within the South African context (Dibley, 2009). The current paper seeks to investigate whether there is a relationship between self-perceived EI and leadership styles and to determine if EI can predict an effective leadership style within the South African petrochemical industry.

The spin-offs of globalisation make the South African petrochemical industry an intriguing milieu within which to examine the relationship between EI and leadership styles (Robbins, Judge, Odendaal \& Roodt, 2009). As with other South African industries, the petrochemical industry has been forced to introduce new business strategies, new management systems, changes in technology and government policy (Stander, 2007). Inevitably, change not only results in the implementation of new systems and processes within any organisation, but also affects the people within this organisational environment (Ndlovu \& Parumasar, 2005). Evidently, leader behaviour is accentuated as being a fundamental determinant of overall organisational effectiveness (Hunter, 2009; Wasylyshyn, 2004). Therefore, business performance will be influenced by how well leaders manage their own and their subordinates' emotions (Goleman, Boyatzis \& McKee, 2002; Hunter, 2009). In this regard, the measurement and development of EI as related to effective leadership can play a significant role (Boateng, 2007; Lam \& O'Higgins, 2012) in aiding the petrochemical industry to drive high performance (Laff, 2008) despite the effects of globalisation.

By linking EI to transformational leadership, the argument is put forth that there is a positive relationship between these constructs. The primary aim of this study is to determine the relationships between self-perceived EI and leadership styles (represented by transformational, transactional and laissezfaire leadership styles), in other words to determine whether EI can predict an effective leadership style within a South African petrochemical organisation. The results can be used for adjusting training and mentoring programmes in the petrochemical and similar South African industrial contexts.

\section{Emotional intelligence}

Despite numerous conceptual definitions of EI (Bar-On, 1997; Goleman, 1995, 1998; Mayer, Roberts \& Barsade, 2008;
Salovey \& Mayer, 1990), they all share some theoretical underpinnings, which include an awareness of one's own emotions; an awareness of emotions in others; an understanding of emotions; and the ability to manage one's own emotions and the emotions of others. Although there is a general agreement regarding EI as a nonacademic intelligence with predictive value beyond general intelligence or ' $\mathrm{g}$ ' (Gardner, 1983; Williams, 2011), there is a growing debate as to how EI should be operationalised. The two prominent models of emotional intelligence include an ability-based model (Ashkanasy \& Daus, 2005; Mayer et al., 2008) and a skill-based model (Petrides, 2010), which differ in their conceptual approach toward the application of EI.

The ability-based model defines EI according to intelligence theory, emphasising the cognitive elements of EI and using a performance-based assessment method known as the MayerSalovey-Caruso Intelligence Test (MSCEIT) (Ashkanasy \& Daus, 2005; Mayer et al., 2008) to distinguish various levels of EI. The skills-based model is trait based and encompasses a broader set of competencies (Petrides, 2010). In this framework, Bar-On (2006) defines EI as being a cross-section of interrelated emotional and social competencies, skills and facilitators that determine how effectively we understand and express ourselves, understand others and relate with them and cope with daily demands (Clarke, 2010). Suffice it to say, each model and its respective inventory has been studied empirically and accepted as a valid measure of EI (Coetzee \& Schaap, 2005; Lam \& O'Higgins, 2012; Ramesar, Koortzen \& Oosthuizen, 2009).

For the purposes of the present study, the self-rating skillsbased emotional quotient inventory (EQ-i) was identified as the instrument of choice (Bar-On, 2006), mainly because of the links between EQ-i and leadership (Barling, Slater \& Kelloway, 2000; Schlechter \& Strauss, 2008), as well as its application in organisational settings (Cooper, 1998; Schlechter \& Strauss, 2008). According to Bar-On (2006), the development of EI will result in increased productivity, loyalty, innovation and performance of individuals, groups and organisations.

Attempting a more holistic approach to being emotionally and socially intelligent means that people need to manage emotions so that their emotions work for them and not against them and so that they are sufficiently optimistic, positive and self-motivated (Bar-On, 2006).

Bar-On's (2006) emotional intelligence model comprises five scales, which include intrapersonal skills, interpersonal skills, stress management, adaptability and general mood, with fifteen subscales:

1. Intrapersonal skills (i.e. self-regard, emotional awareness, assertiveness, independence and self-actualisation).

2. Interpersonal skills (i.e. empathy, social responsibility and interpersonal relationships).

3. Stress management (i.e. stress tolerance and impulse control). 
4. Adaptability (i.e. reality testing, flexibility and problem solving).

5. General mood (i.e. optimism and happiness) (Bar-On, 2006).

According to McCallum and Piper (2000), the model proposed by Bar-On is perhaps the clearest and most comprehensive to date (Bar-On, 1997; 2004; 2006).

\section{Emotional intelligence and demographic variables}

Researchers have often studied demographic differences in relation to EI (Stough, Saklofske \& Parker, 2009). However, research on gender differences in EI has been limited. Studies conducted by Mayer, Salovey and Caruso (2000) in 2000 and Van Rooy, Dilchert, Viswesvaran and Ones in 2006 indicate that women score higher on measures of EI than men. Women have also been shown to have more complex emotion knowledge (Ciarrochi, Hynes \& Crittenden, 2005), empathy (Bar-On, 2000) and social skills (Eagly \& Johnson, 1990).

Previous research regarding EI and management levels found that not only are social and emotional skills essential for executive level leaders but, as individuals ascend the organisational hierarchy, emotional intelligence also becomes an increasingly relevant determinant of who will and will not be successful (Hooijberg, Hunt \& Dodge, 1997; Zaccaro, 2001). In addition, other findings indicated that emotionallyintelligent senior managers perform better on the job and that there is a strong relationship between superior performance in leaders and emotional competence (Cavallo \& Brienza, 2001; Cooper, 1997).

Roberts, Zeidner and Matthews (2001) conducted one of the few studies that evaluated ethnic group differences in EI and found conflicting results. In an American context, Van Rooy, Alonso and Viswesvaran (2005) found that Black people scored higher than White people on the total EI scale, equal to a Cohen's $d$ of 0.32 .

\section{Leadership styles}

Burns (1978, p. 1) wrote that: '[o]ne of the most universal cravings of our time is a hunger for compelling and creative leadership'. This opinion is as relevant today as it was 30 years ago. Leadership continues to be one of the most passionately-debated topics, both in practice and in research (Cameron, Dutton \& Quinn 2003; Northouse, 2012).

Three different leadership styles, specifically transformational, transactional and laissez-faire, have been shown to reflect the full range of leadership styles (Bass, 1985, 1990; Bass \& Avolio, 1994). This is measured by the Multifactor Leadership Questionnaire (MLQ Form 5X, Version 2009) (Avolio, Bass \& Jung, 1995). Research on these leadership styles has shown that the transformational leadership style is typically more effective than the transactional and laissez-faire leadership styles (Avolio et al., 1995; Gardner, Lowe, Moss, Mahoney \&
Cogliser, 2010). Consequently, transformational leadership has been the basis of various conceptual and empirical debates in literature over the past decade (Northouse, 2012). Transformational leadership is defined as being an approach to leadership wherein the leader identifies the needed change, creates a vision to guide the change by inspiring their followers and executes the change with the commitment of their followers (Bass \& Riggio, 2006; Northouse, 2012). Furthermore, this approach challenges leaders to be creative with regard to problem solving and to develop the leadership capacity of their followers through coaching and mentoring and by providing both challenges and support (Bass \& Bass, 2008; Northouse, 2012).

According to Bass (1985), four factors that are characteristic of transformational leadership are proposed, commonly referred to as the four 'I's:

1. Idealised influence (i.e. followers idealise and emulate the behaviours of their trusted leader).

2. Inspirational motivation (i.e. followers are motivated by the attainment of a common goal).

3. Intellectual stimulation (i.e. followers are encouraged to break away from old ways of thinking and are encouraged to question their values, beliefs and expectations).

4. Individualised consideration (i.e. followers' needs are addressed both individually and equitably) (Bass \& Avolio, 1997).

Bass (1997, p. 133) state that: 'using a carrot or a stick, transactional leadership is usually characterised as instrumental in followers' goal attainment'. The transactional leadership process builds upon exchange: the leader offers rewards (or threatens punishments) for the performance of desired behaviours and the completion of certain tasks. This type of leadership may result in followers' compliance, but is unlikely to generate enthusiasm for and a commitment to task objectives (Zagoršek, Dimovski \& Škerlavaj, 2009). There are three components to transactional leadership: contingent reward, whereby subordinates' performance is associated with contingent rewards or exchange relationship; active management-by-exception, whereby leaders monitor followers' performance and take corrective action if deviations occur to ensure that outcomes are achieved; and passive management-by-exception, whereby leaders fail to intervene until problems become serious (Bass, 1997).

A laissez-faire leadership style, on the other hand, can be described as non-leadership or the avoidance of leadership responsibilities. Leaders fail to follow up requests for assistance and resist expressing their views on important issues (Bass, 1997).

By comparison, transformational leadership is more emotionbased than transactional and laissez-faire leadership (Chuang et al., 2012; Yamminaro \& Dubinsky, 1994). Consequently, a number of authors have suggested that underpinning transformational leadership is the enhanced emotional attachment to the leader (Ashkanasy \& Tse, 2000; Dulewicz \& Higgs, 2003) that arises as a result of leaders using emotional intelligence. 
In view of the positive organisational outcomes associated with transformational leadership, researchers are exploring factors that predict transformational leadership behaviours (Northouse, 2012; Rost, 1991). Such factors will contribute to the theoretical elaboration of transformational leadership theory and have the potential to improve leader training and selection (Clarke, 2006). Unmistakably, EI has shown considerable promise as a possible leadership antecedent (Bass \& Avolio, 1994; Harms \& Credé, 2010).

Today's effective leadership skills have partly been described on the understanding of emotions and EI (Cooper \& Sawaf, 1997; Schlechter \& Strauss, 2008). Therefore, inconclusive data remains as to what extent EI accounts for effective leadership (Harms \& Credé, 2010).

\section{Leadership styles and demographic variables}

Although past research on leadership style differences between men and women has been inconclusive (Carless, 1998; Eagly \& Johnson, 1990), research on leadership and gender concluded that, amongst managers, women tended to be more democratic in their leadership styles compared with men (Eagly \& Carli, 2003). They also reported that a meta-analysis of 45 studies examining gender differences in transformational leader behaviours found that, compared with male leaders, female leaders used and exhibited a more desirable transformational style.

Regarding leadership styles and management levels, executive leaders portray transformational leadership more than transactional leadership (Bass, Waldman, Avolio \& Bebb, 1987; Katz \& Kahn, 1978).

The few studies that do examine ethnic or racial differences are limited in their description of the differences in leadership style between leaders from the minority versus dominating groups (Eagly \& Johnson, 1990). Booysen (2001) examined racial differences in the behaviour of managers and found that White managers were more bottom-line driven in their cultural orientation whilst Black managers were more people focused. This suggests that Black managers may be more inclined toward a transformational leadership style. In contrast to Booysen's results, Thomas and Bendixen (2000) found no cultural differences amongst the managers in their study.

\section{Emotional intelligence and leadership styles}

All three leadership styles are displayed at various times and to various degrees (Avolio, 1999). According to Snodgrass and Schachar (2008), both transformational and transactional leadership styles have been found to correlate positively with organisational outcomes in studies of various types of organisation. Bass (1997) suggests that transformational leaders achieve higher levels of success in the workplace than transactional leaders. They produce better financial results (are bottom-line driven) and are rated as being more satisfying and effective than transactional leaders (Snodgrass
\& Schachar, 2008). In sum, the empirical literature shows repeatedly that transformational leadership is associated positively with leader effectiveness (Bass \& Avolio, 2004; Northouse, 2012).

Subsequently, Gardner and Stough (2002), Barbuto and Burbach (2006), Harms and Credé (2010) as well as Hur et al. (2011) showed that the EI of leaders accounted for the majority of the variance in transformational leadership. However, this has not yet been established for the South African petrochemical context and is therefore of importance in this study.

Although there has been much research illustrating the effectiveness of transformational leadership behaviour in organisations (Judge \& Piccolo, 2004; Northouse, 2012), there has been a deficiency in research investigating the antecedents of these behaviours (Harms \& Credé, 2010). Whilst there are fewer theoretical underpinnings to guide hypotheses regarding the relationship of transactional and laissez-faire styles of leadership with EI, it has been suggested that to provide the effective and equitable exchange characteristic of contingent reward behaviours, leaders should have the abilities and traits associated with elevated EI (Barling et al., 2000). Because active management-byexception behaviours reflect reactive and routine leadership behaviours that need no insight or empathy, it is not likely that there would be any relationship with EI (Barling et al., 2000). However, it is expected that EI would show negative relationships with passive management-by-exception and laissez-faire leadership behaviours, because individuals with elevated EI are thought to be higher on initiative and selfefficacy (Goleman et al., 2002).

Furthermore, women (Eagly \& Carli, 2003; Van Rooy et al., 2006), Black people (Booysen, 2001; Van Rooy et al., 2005) and senior managers (Katz \& Kahn, 1978; Zaccaro, 2001) should show positive relationships with EI and transformational leadership.

The relationship between EI and leadership styles and determining whether EI can predict an effective leadership style needs more investigation, particularly within the South African petrochemical context. By studying the relationship between EI and effective leadership further, the study aims at contributing to the EI and leadership literature. This may provide valuable significance for organisations' endeavours with regard to improving, training and identifying alternative selection and assessment procedures for evaluating leaders' strengths and developmental areas and reviewing how executive decisions shape the behaviour of the organisation as a whole.

The theoretical framework presented in the previous section suggests that the constructs of EI and leadership styles are related conceptually. However, the relationship between EI and leadership styles needs to be investigated empirically. This study focused primarily on finding empirical linkages between EI and selected leadership styles. 
The following specific research hypotheses were formulated:

Hypothesis 1: There is a significant positive relationship between individuals' emotional intelligence and transformational leadership style.

Hypothesis 2: There is a significant positive relationship between individuals' emotional intelligence and transactional leadership style.

Hypothesis 3: There is a significant negative relationship between individuals' emotional intelligence and laissezfaire leadership style.

Hypothesis 4: There is a significant difference between the EQ scores of respondents from different job levels and between race groups.

Hypothesis 5: There is a significant difference between the leadership scores of respondents from different management levels and between race groups.

\section{Research design}

The research was designed within the frame of a positivist research paradigm.

\section{Research approach}

A quantitative data survey design was used to answer the research objectives. The specific survey design can be classified as being both descriptive and exploratory with regard to the EI and leadership styles within a South African petrochemical organisation (Cohen, Manion \& Morrison, 2007). The research used both self-reported primary data collected via survey research (EQ) and secondary selfreported data already collected by the organisation (MLQ). The MLQ data were considered to be valid and were stored by the South African petrochemical organisation in an accessible database.

\section{Research method}

\section{Research participants}

This study utilised probability sampling, as well as a specific method called stratified random sampling, which forms part of probability sampling (Tredoux \& Durrheim, 2006). The sampling design was used to collect the data for the EQ questionnaire. The sample frame, a complete list of all members of the population in which the researcher was interested, was defined as being a database of leaders who already had valid MLQ data on file and who were currently working in a large global organisation in the energy sector of the industry.

These sampling methods identified a subset of the population as well as giving each element of the population being studied a chance of being selected (Cohen et al., 2007). The total population was 950 . The target was $N=370$, but only 162 individuals responded to the request to participate. Of these, 161 questionnaires could be used. One questionnaire was submitted in an incorrect format, which made it impossible to encode. The percentage of the sample that responded was thus $43 \%$. Pallant, (2001) indicates that for this type of research, the minimum number of respondents required would be 150. A total of 161 respondents were therefore deemed to constitute an acceptable response rate. The final sample of 161 respondents included senior, middle and supervisory-level leaders. The inclusion of these categories of leaders was based on the premise that effective leadership is not confined to the occupants of the highest or most prominent positions in terms of influencing others (Bass \& Avolio, 1994) - such leaders can be found at all levels of the organisations' hierarchies (Avolio, 1999).

The demographic characteristics of the sample are summarised in Table 1.

According to Table 1, the majority of the participants were at the supervisory level (59\%), White (62.1\%), men (91.9\%) and between the ages of 40 and $49(56 \%)$. The majority of the participants had between 26 and 30 (61\%) years of experience.

The sample distribution roughly reflects the expectations one has of leaders in this sector, that is, that they are White and predominantly male. Therefore, the sample results can be interpreted with a greater degree of confidence as being representative of the broader population of leaders in this organisation.

\section{Measuring instruments}

The following questionnaires were used in the empirical study:

Demographic questionnaire: A demographic questionnaire was compiled and used in order to gather information

TABLE 1: Respondents' demographic details.

\begin{tabular}{|c|c|c|c|}
\hline Item & Category & $f$ & $\%$ \\
\hline \multirow[t]{4}{*}{ Race } & African & 49 & 30.4 \\
\hline & Mixed-race & 2 & 1.2 \\
\hline & Indian & 10 & 6.2 \\
\hline & White & 100 & 62.1 \\
\hline \multirow[t]{2}{*}{ Gender } & Male & 148 & 91.9 \\
\hline & Female & 13 & 8.1 \\
\hline \multirow[t]{4}{*}{ Age } & $20-29$ years & 7 & 4.3 \\
\hline & $30-39$ years & 43 & 26.7 \\
\hline & $40-49$ years & 56 & 34.8 \\
\hline & $50-60$ years & 55 & 34.2 \\
\hline \multirow[t]{7}{*}{ Qualification } & Master's degree & 5 & 3.1 \\
\hline & Honours degree & 14 & 8.7 \\
\hline & Degree & 27 & 16.8 \\
\hline & Diploma & 24 & 14.9 \\
\hline & Certificate & 36 & 22.3 \\
\hline & Matric & 43 & 26.7 \\
\hline & Other & 12 & 7.5 \\
\hline \multirow[t]{5}{*}{ Years of experience } & $1-10$ years & 25 & 15.5 \\
\hline & $11-20$ years & 25 & 15.5 \\
\hline & $21-25$ years & 36 & 22.4 \\
\hline & $26-30$ years & 61 & 37.9 \\
\hline & $31-40$ years & 14 & 8.7 \\
\hline \multirow[t]{3}{*}{ Management level } & Senior management & 19 & 11.8 \\
\hline & Middle management & 47 & 29.2 \\
\hline & Supervisor & 95 & 59 \\
\hline
\end{tabular}

$f$, frequency. 
relating to the race, gender, age, qualifications, years of experience and job levels (senior, middle and supervisory) of the participants.

EQ-i: To measure emotional intelligence, the EQ-i (Bar-on, 2006) was used. The EQ-i is a self-report inventory comprising 133 declarative statements phrased in the first person singular. Participants are required to indicate the degree to which each statement is true of the way they typically think, feel or act on a five-point response scale ranging from (1) 'very seldom or not true of $\mathrm{me}^{\prime}$ to (5) 'very often true of me or true of me'. The items of the EQ-i are added up to yield scores on 15 lower-order subscales, five higherorder composite scales and an overall EI score. High scores indicate a high level of EI (Palmer, Gardner \& Stough, 2003). Psychometric analyses of the EQ-i reported in the technical manual (Bar-On, 2006) indicate that it has good internal reliability and test-retest reliability. With a South African sample $(N=9892)$ the Cronbach's alphas were high for all of the subscales, ranging from 0.69 (Social Responsibility) to 0.86 (Self-Regard). The alpha coefficients were also high for all of the composite scales, ranging from 0.82 (General Mood and Stress Management) to 0.92 (Intrapersonal) (Bar-On, 2006). The EQ-i was completed online and raw scores were accessed from the test developer.

Multifactor Leadership Questionnaire: Leadership styles were measured using the Multifactor Leadership Questionnaire (MLQ) (Form 5X, Version 2009) (Bass \& Avolio, 1997). Although the multi-rater format was used in this study, only self-ratings of leaders were used. The MLQ Form used contains 45 questions using a five-point scale ranging from (0) not at all to (4) frequently, if not always. It is a 36-item measure of leadership style assessing transformational, transactional and laissez-faire leadership behaviours. The nine items that measure leadership outcomes were eliminated for the purpose of this study. According to the MLQ technical manual (Bass \& Riggio, 2006), acceptable internal consistencies of approximately 0.80 were reported on all scales. For a sample of 1200 employees from several diverse organisations (commercial businesses, healthcare organisations, welfare institutions and local governments), Den Hartog, van Muijen and Koopman (2011) found that the internal consistency of transformational leadership ranged from 0.72 to 0.93 ; transactional leadership ranged from 0.58 to 0.78 ; and laissez-faire leadership was 0.49 .

\section{Administration procedure}

In order for research to be conducted in the South African petrochemical industry, initial permission had to be obtained from the senior psychologists supervising the ethical use of assessments, followed by authorisation from the human resources (HR) manager and the managing director of the business that was selected for the study. The HR manager sent out a communication to all HR officers and leaders informing them of the study and inviting them to participate. This ensured that the participants were provided with a standard briefing. The briefing included matters such as voluntary participation, informed consent, confidentiality and the purpose and aim of the study, including the focus of the various questionnaires. This was followed by a complete explanation of each of the instruments. It was also made clear that volunteering and consenting to complete the online EQ-i automatically consented to the use of existing MLQ data. The participants then completed the online EQ-i questionnaire. The demographic information and EQ-i in raw data format were provided to the researcher by Jopie Van Rooyen and Partners as per contracted legal agreement. The MLQ data were accessed from the organisation's archives.

\section{Statistical analyses}

Statistical analyses were carried out by means of the Statistical Package for Social Sciences (SPSS) computer program for Windows ${ }^{\circledR}$ version 18.0 (SPSS Inc., 2010). Descriptive statistics were obtained for all dependent and independent variables. Cronbach's alpha was used to determine the internal consistency of the measuring instruments. Pearson productmoment correlations were calculated to assess the direction and strength of the relationships between the variables and the significance level was set at 0.05 . For the purposes of this study, $r$ values larger than 0.30 were considered to have a medium to large practical effect (Cohen, 1992). Multiple regression analysis was used to determine whether EI predicts leadership styles (transformational, transactional, laissez-faire). Additionally, analysis of variance (ANOVA) tests were performed to determine whether individuals from different management levels differed in terms of their EI and leadership styles. A $t$-test was used to determine whether Black and White respondents differed in their scores.

\section{Results}

\section{Descriptive statistics and Cronbach's alpha}

Descriptive statistics were calculated for both the independent variable (EI) and the dependent variable (leadership styles). Table 2 presents the means, standard deviations, minimum and maximum scores and Cronbach's alpha reliability coefficients for the sample of leaders, using the EQ-i and adapted version (2009) of the MLQ (Form 5X).

According to Nunnally and Bernstein (2010), Cronbach's alpha coefficients of between 0.5 and 0.6 are acceptable for

TABLE 2: Descriptive statistics and Cronbach's alphas for emotional quotient inventory and Multifactor Leadership Questionnaire (Form 5X, Version 2009) $(N=161)$.

\begin{tabular}{llllll}
\hline Scale & M & SD & Minimum & Maximum & $\begin{array}{l}\text { Cronbach's } \\
\text { alpha }\end{array}$ \\
\hline EQ-i scale & & & & & \\
Total EQ & 4.03 & 0.43 & 2.10 & 4.82 & 0.96 \\
Intrapersonal skills (IA) & 4.05 & 0.53 & 2.40 & 5.00 & 0.93 \\
Interpersonal skills (IE) & 4.01 & 0.50 & 1.60 & 4.90 & 0.89 \\
Stress management (ST) & 3.90 & 0.52 & 1.90 & 4.80 & 0.83 \\
Adaptability (AD) & 4.16 & 0.47 & 2.00 & 5.00 & 0.87 \\
General mood (GM) & 4.01 & 0.46 & 2.00 & 4.90 & 0.82 \\
MLQ scale & & & & & \\
Transformational (TL) & 2.05 & 0.45 & 0.50 & 3.90 & 0.87 \\
Transactional (TA) & 2.05 & 0.45 & 0.50 & 3.90 & 0.58 \\
Laissez-faire (LF) & 0.59 & 0.64 & 0.00 & 3.00 & 0.61 \\
\hline
\end{tabular}

$\mathrm{M}$, mean; SD, standard deviation; EQ-i, emotional quotient inventory; MLQ, Multifactor Leadership Questionnaire. 
basic research purposes, whereas coefficients of 0.8 and higher are considered to be important or ideal. From Table 2 , it can be seen that the instruments have maintained an acceptable level of internal consistency, with the coefficients ranging from moderate to high, thus demonstrating reliability ( 0.58 for transactional to 0.96 for total EQ). The Cronbach's alpha coefficients for each scale were as follows: Total EQ (0.96), intrapersonal skills (0.93), interpersonal skills $(0.89)$, stress management $(0.83)$, adaptability $(0.87)$, general mood (0.82), transformational leadership (0.87), transactional leadership (0.58) and the laissez-faire scales (0.61). The transactional and laissez-faire scales show lower reliabilities and were investigated using an item analysis, yet could not be improved to yield a Cronbach's alpha over the 0.7 level; so it was decided to keep these two scales unchanged.

The means and standard deviations of the subscales are also presented in Table 2. The table shows that managers scored the highest on adaptability $(\mathrm{M}=4.16, \mathrm{SD}=0.47)$ and the lowest on stress management $(\mathrm{M}=3.90, \mathrm{SD}=0.52)$. The other EQ dimensions scored relatively consistently around the 4 out of 5 level. These were intrapersonal skills $(\mathrm{M}=4.05, \mathrm{SD}$ $=0.53)$, general $\operatorname{mood}(\mathrm{M}=4.01, \mathrm{SD}=0.52)$ and interpersonal skills $(4.01, \mathrm{SD}=0.50)$.

\section{Correlations between emotional quotient (EQ-i) and leadership styles}

Correlations were computed between the components of EQ (EQ-i) and leadership styles (MLQ). The correlations are presented in Table 3. The table also presents the intercorrelations between the dimensions of the same scale (i.e. between the subscales of EQ and between the subscales of MLQ).

Table 3 indicates that the subscales of EQ correlate very highly with one another. For example adaptability correlates strongly with Intrapersonal Skills (EQ $(r=0.84 ; p<0.001$; large practical effect size). Intrapersonal skills also show a particularly high correlation with GM $(r=0.81 ; p<0.001$; large practical effect size). Whilst these two examples were highlighted specifically, all of the correlations between the subscales of EQ are large $(r>0.5)$.

Transformational and transactional leadership show small significant correlations with one another $(r=-0.19 ; p=0.017$; small practical effect size) and although transformational leadership correlates negatively with laissez-faire leadership $(r=-0.33 ; p<0.000$; large practical effect size), there are no significant correlations overall between transactional and laissez-faire leadership $(r=0.09 ; p=0.254)$.

Table 3 indicates that all of the EQ dimensions correlate significantly with transformational leadership: stress management ( $r=0.21 ; p=0.002$; small practical effect size); total EQ $(r=0.31 ; p<0.001$; medium practical effect size); adaptability $(r=0.30 ; p<0.000$; medium practical effect size); general mood $(r=0.33 ; p<0.001$; medium practical effect size); intrapersonal skills ( $r=0.26 ; p=0.001$; small practical effect size); interpersonal skills $(r=0.27 ; p=0.001$; small practical effect size).

Positive correlations indicate that the higher a respondent scored on EQ, the higher they also scored on transformational leadership. Neither total EQ nor its dimensions showed any significant relationships with the transactional leadership style, with the exception of a small negative correlation between transactional leadership and stress management ( $r=-0.19 ; p=0.017$; small practical effect size).

Laissez-faire does show a significant relationship with all but one EQ dimension (interpersonal skills); however this time the correlations are negative, indicating that the lower the respondents score on the laissez-faire style, the higher

TABLE 3: Intercorrelations between emotional quotient and constructs with leadership styles.

\begin{tabular}{|c|c|c|c|c|c|c|c|c|c|}
\hline \multirow[t]{2}{*}{ Variables } & \multicolumn{6}{|c|}{ EQ } & \multicolumn{3}{|c|}{ Leadership Styles } \\
\hline & Total EQ & INTRA & INTER & ST & $A D$ & GM & TL & TA & LF \\
\hline \multirow[t]{2}{*}{ Total EQ } & 1 & $0.92 * * *$ & $0.84 * * *$ & $0.86^{* * *}$ & $0.91^{* * *}$ & $0.89 * * *$ & $0.31 * * *$ & -0.07 & $-0.27^{* *}$ \\
\hline & - & 0.000 & 0.000 & 0.000 & 0.000 & 0.000 & 0.000 & 0.381 & 0.001 \\
\hline \multirow[t]{2}{*}{ INTRA } & - & 1 & $0.68^{* * *}$ & $0.73 * * *$ & $0.84 * * *$ & $0.81 * * *$ & $0.26 * *$ & -0.08 & $-0.31 * * *$ \\
\hline & - & - & 0.000 & 0.000 & 0.000 & 0.000 & 0.001 & 0.328 & 0.000 \\
\hline \multirow[t]{3}{*}{ INTER } & - & - & 1.00 & $0.60 * * *$ & $0.67^{* * *}$ & $0.73 * * *$ & $0.27 * *$ & 0.03 & $-0.17^{*}$ \\
\hline & - & - & - & 0.000 & 0.000 & 0.000 & 0.001 & 0.734 & 0.035 \\
\hline & - & - & - & 1.00 & $0.76^{* * *}$ & $0.67 * * *$ & $0.21 * *$ & $-0.19 *$ & $-0.21 * *$ \\
\hline ST & - & - & - & - & 0.000 & 0.000 & 0.008 & 0.017 & 0.007 \\
\hline \multirow[t]{2}{*}{$A D$} & - & - & - & - & 1.00 & $0.75^{* * *}$ & $0.30 * * *$ & -0.04 & $-0.29 * * *$ \\
\hline & - & - & - & - & - & 0.000 & 0.000 & 0.584 & 0.000 \\
\hline \multirow[t]{2}{*}{ GM } & - & - & - & - & - & 1.00 & $0.33 * * *$ & -0.01 & $-0.20 * *$ \\
\hline & - & - & - & - & - & - & 0.000 & 0.864 & 0.013 \\
\hline TL & - & - & - & - & - & - & 1.00 & $0.19 * *$ & $-0.33^{* * *}$ \\
\hline \multirow[t]{2}{*}{ TA } & - & - & - & - & - & - & - & 1.00 & 0.09 \\
\hline & - & - & - & - & - & - & - & - & 0.254 \\
\hline \multirow[t]{2}{*}{ LF } & - & - & - & - & - & - & - & - & 1.00 \\
\hline & - & - & - & - & - & - & - & - & - \\
\hline
\end{tabular}

EQ, emotional quotient; INTRA, intrapersonal; INTER, interpersonal; ST, stress management; AD, adaptability; GM, general mood; TL, Transformational; TA, transactional; LF, laissez-faire. ${ }^{*}, p<0.05$ (two-tailed); ${ }^{* *}, p<0.01 ; * * *, p<0.001$. 
they score on the EQ dimension, Interpersonal Skills. The following correlations were found between EQ and laissezfaire: Total EQ $(r=-0.27 ; p=0.001$; small practical effect size); intrapersonal skills $(r=-0.31 ; p<0.000$; medium practical effect size); Interpersonal Skills $(r=-0.17 ; p=0.035$; small practical effect size), stress management $(r=-0.21 ; p=0.007$; small practical effect size), adaptability $(r=-0.29 ; p<0.000$; small practical effect size) and general $\operatorname{mood}(r=-0.20$; $p=0.013$; small practical effect size).

\section{Multiple regression analyses}

As part of the general aim of finding and understanding empirical linkages between emotional intelligence and leadership styles (represented by transformational, transactional and laissez-faire leadership styles), standard multiple regressions were performed.

The high correlations between the EQ dimensions $(r>0.7)$ indicate the existence of possible multicollinearity. On investigation, variance inflation factor (VIF) statistics showed values of over 4 . Although the general rule is that VIF values of under 10 are acceptable, according to Field (2005), if no formal VIF value for determining the presence of multicollinearity exists, it is suggested that VIF values exceeding 10 should be regarded as indicators of multicollinearity. However, in weaker models, values of above 2.5 may be a cause for concern. The models in this study only explain a very small percentage of the dependent variable and it was thus decided to run only total EQ as the subdimensions were too closely correlated.

The aim was to understand what predictive value EQ could have on the leadership style of a manager. Therefore, two standard multiple regressions (using the enter method) were performed where transformational and laissez-faire leadership were the dependent variables and Total EQ was the independent variable in each regression. As there is no significant correlation between EQ and transactional leadership, no regression was run for this MLQ scale.

Table 4 summarises the results from the two regression analyses.

Table 4 indicates that the Total EQ explained small practical effect size percentages of variance $\left(R^{2} \leq 0.12\right)$ in the dependent variable transformational leadership (Cohen, 1992). The $F$ values for transformational leadership were significant statistically ( $p \leq 0.001$ ), indicating that the regression is significant, yet the adjusted $R^{2}$ value (0.089) indicates that only $8.9 \%$ of the variance in transformational leadership is explained by the regression model.

Similarly, the $F$ value for the regression analysis with laissezfaire leadership as the dependent variable is also significant, yet the adjusted $R^{2}$ value is 0.066 , which also indicates a rather small effect size $\left(R^{2} \leq 0.12\right)$. Therefore Total EQ only explains $6.6 \%$ of the variance in laissez-faire leadership.

\section{Tests for significant mean differences between demographic groups}

Two demographic variables of importance were selected for further investigation: management level and race. Gender had to be omitted as the female group only represented 13 women. The gender variable is split: $92 \%$ men and $8 \%$ women. It was therefore decided not to investigate this any further as the difference between the groups was too vast.

The parametric ANOVA test was used to test the differences between the three management level groups. The results of the test are shown in Table 5.

The results indicate that the different management groups did not differ significantly in terms of EI, transformational or laissez-faire style of leadership. There does appear to be a linear relationship between management group and transactional leadership, as respondents in the junior group (first line managers/supervisors) scored significantly higher than respondents in the middle and senior managers $(M)$ categories (Junior $M$ Rank = 94.66; Middle $M$ Rank = 65.46; Senior $M$ Rank = 51.13).

A comparison between race groups was only possible between Black $(n=49)$ and White $(n=100)$ respondents. The base sizes of the other two race groups (Mixed-race and Indian) were considered to be too small for consideration ( $n$ $=2$ and $n=10$ respectively). An independent $t$-test was used and the results are presented in Table 6.

There is a significant difference between Black and White leaders yet again with regard to adaptability $(p=0.005)$, with Black respondents showing a significantly higher score than the White leaders $(\mathrm{M}=4.17$ vs. $\mathrm{M}=3.86)$. In general,

TABLE 4: Summary of standard multiple regression analyses: Total emotional quotient (independent variables) and leadership styles (dependent variables) ( $N=161)$.

\begin{tabular}{|c|c|c|c|c|c|c|c|c|}
\hline \multirow[t]{2}{*}{ Variables } & \multicolumn{2}{|c|}{ Unstandardised Coefficient } & \multirow[t]{2}{*}{ Standardised coefficient (B) } & \multirow[t]{2}{*}{$t$} & \multirow[t]{2}{*}{$p$} & \multirow[t]{2}{*}{$\boldsymbol{F}$} & \multirow[t]{2}{*}{ Adjusted $R^{2}$} & \multirow[t]{2}{*}{$\boldsymbol{R}$} \\
\hline & B & SE B & & & & & & \\
\hline Transformational leadership & - & - & - & - & - & 16.70 & 0.089 & $0.31^{\circ}$ \\
\hline (Constant) & 1.84 & 0.32 & - & 5.75 & 0.000 & - & - & - \\
\hline Total EQ-i & 0.323 & 0.08 & 0.31 & 4.09 & 0.000 & - & - & - \\
\hline Laissez-faire leadership & - & - & - & - & - & 12.32 & 0.066 & $0.27^{\circ}$ \\
\hline (Constant) & 2.190 & 0.460 & - & 4.764 & 0.000 & - & - & - \\
\hline Total EQ-i & -0.398 & 0.113 & -0.268 & -3.511 & 0.001 & - & - & - \\
\hline
\end{tabular}

EQ-I, emotional quotient; B, beta; $\mathrm{SE} B$, standard error of beta; $t, t$-test; $p, p$-value; $F, F$-test; Adjusted $R^{2}$; proportion variance explained, $R$, multiple correlation.

a, $R^{2} \leq 0.12$ (small practical effect size)

, $R^{2} \geq 0.13 \leq 0.25$ OR $0.13 \leq R^{2} \leq 0.25$ (medium practical effect size

', $R^{2} \geq 0.26$ (large practical effect size) 
TABLE 5: Significant differences between management level groups: Analysis of variance (ANOVA).

\begin{tabular}{|c|c|c|c|c|c|}
\hline Scale & Junior Management Mean & Middle Management Mean & Senior Management Mean & $F$ & Asymp. Sig. \\
\hline Total emotional quotient & 4.00 & 4.07 & 4.06 & 0.56 & 0.571 \\
\hline Intrapersonal skills (IA) & 3.12 & 3.12 & 3.27 & 0.07 & 0.936 \\
\hline Interpersonal skills (IE) & 2.17 & 1.90 & 1.79 & 1.42 & 0.246 \\
\hline Stress management (ST) & 3.86 & 3.95 & 3.96 & 0.94 & 0.391 \\
\hline Adaptability (AD) & 4.00 & 4.00 & 4.04 & 10.08 & $0.000^{* * * \dagger}$ \\
\hline General mood (GM) & 4.10 & 4.23 & 4.23 & 0.55 & 0.578 \\
\hline Transformational (TL) & 4.05 & 4.08 & 4.00 & 0.16 & 0.852 \\
\hline Transactional (TA) & 3.97 & 4.11 & 4.09 & 1.50 & 0.227 \\
\hline Laissez-faire (LF) & 0.52 & 0.66 & 0.70 & 1.08 & 0.341 \\
\hline
\end{tabular}

$F, F$-test; Asymp. Sig., Asymptotic significance.

$*, p \leq 0.05 ; * *, p \leq 0.01 ; * * \dagger, p \leq 0.001$

TABLE 6: Significant differences between race groups: $t$-test.

\begin{tabular}{lllll}
\hline Scale & Black (M) & White (M) & $\boldsymbol{t}$ & Asymp. Sig. \\
\hline Total emotional quotient & 4.13 & 3.99 & 1.87 & 0.064 \\
Intrapersonal skills (IA) & 4.18 & 4.01 & 1.95 & 0.054 \\
Interpersonal skills (IE) & 4.08 & 4.00 & 0.94 & 0.348 \\
Stress management (ST) & 4.03 & 3.86 & 1.92 & 0.057 \\
Adaptability (AD) & 4.17 & 3.94 & 2.83 & $0.005^{* *+}$ \\
General mood (GM) & 4.19 & 4.13 & 0.64 & 0.522 \\
Transformational (TL) & 3.22 & 3.08 & 1.84 & 0.068 \\
Transactional (TA) & 2.08 & 2.04 & 0.55 & 0.585 \\
Laissez-faire (LF) & 0.47 & 0.65 & -1.52 & 0.130 \\
\hline
\end{tabular}

$\mathrm{M}$, mean; $t$, $t$-test; Asymp. Sig., Asymptotic significance.

$*, p \leq 0.05 ; * * \dagger, p \leq 0.01$

Black leaders scored higher on all EQ scales and Total EQ and intrapersonal skills are only just outside the set level of statistical significance (i.e. just over $p<0.05$ ).

\section{Discussion}

This study examined the relationship between overall self-perceived EI, the components thereof as well as the components of the full range model of leadership: transformational, transactional and laissez-faire leadership styles (Bass \& Avolio, 1997).

The results indicate that the EQ-i scales have acceptable and high levels of internal consistency, with all Cronbach's alpha values falling above 0.8. The MLQ (Form 5X, Version 2009) also has acceptable high levels of internal consistency for transformational leadership and acceptable moderate levels for transactional and laissez-faire leadership. Botha (2002) found the MLQ instrument to be a reliable measure of transformational leadership and a poor measure of transactional leadership. Although results were based on self-ratings only, previous findings were re-examined and reaffirmed in this study. Overall, both measures were reported as being reliable within the multicultural South African petrochemical organisation under study.

However, it should be noted that the means and the scales are high and that the standard deviations are low, that is to say, in general two-thirds of the ratings were in the range of 3.5 to 4.5 on a five-point scale. These high scores can be attributed largely to the use of data obtained through selfratings. This fact might also explain the high correlations reported between the subscales of EQ.
In this light, significant positive relationships were demonstrated between EI and transformational leadership giving support to Hypothesis 1 (see Barbuto \& Burbach, 2006). Although some of the correlations are small $(r<0.3)$, there were a few medium-sized correlations (Total EQ, adaptability and general mood) (Petrides, Frederickson \& Furnham, 2004). It can thus be concluded that there is a significant positive relationship between EI (intrapersonal skills, interpersonal skills, adaptability, stress management, general mood) and transformational leadership style. the correlations revealed that the ability to perceive and adapt emotions effectively has a strong relationship with transformational leadership style $(r=0.30)$. This implies that in the petrochemical organisation, leaders with higher EI may, to a small extent, predict effective leadership (transformational leadership style) (Bass \& Avolio, 2004; Gardner et al., 2010), which supports Hypothesis 4. These findings were in support of, although admittedly nowhere as strong as, other research outcomes by Leban (2003) and Piel (2008), which demonstrated strong statistically-inferred predictive relationships between EI and transformational leadership. On the other hand, Leban's (2003) and Piel's (2008) research strategies used 360-degree review feedback on the leaders compared with the self-report in this research, which may reduce the contribution of this study.

In contrast, with the exception of one small correlation with stress management, no significant relationship was found between EI and transactional leadership (not supporting Hypothesis 2). Few theoretical underpinnings to guide hypotheses regarding the relationship of transactional styles of leadership with EI have been suggested in the literature. To provide the effective and equitable exchange characteristic of contingent reward behaviours, leaders should have abilities and traits associated with elevated EI (Barling et al., 2000). This indicates that leaders who are more transactionally inclined within this petrochemical organisation may display less self-perceived EI.

As anticipated, a negative relationship was found between laissez-faire leadership and overall EI, intrapersonal skills, adaptability, stress management and general mood (in support of Hypothesis 3). The sizes of the correlations are medium to small with the largest correlation being between laissez-faire and intrapersonal skills (-0.31). There is thus some support for the fact that those leaders who were absent when 
required and failed to follow up on requests for assistance (Bass, 1997) were more unlikely to effectively perceive and manage their emotions than those of others in the workplace. This may indicate that leaders within this petrochemical organisation who are able to identify with and express their feelings constructively and confidently, and who live and work independently and cope effectively with demanding situations, will be less likely to demonstrate absent leadership.

The regression analysis shed more light on the relationship between EQ and leadership styles. Total EQ was used as the independent variable and each of transformational and laissez-faire leaderships were in turn the dependent variables. EQ explains only $8.9 \%$ of the variance in transformational leadership and a small $6.6 \%$ in laissez-faire leadership. Whilst these are relatively small values which do not provide strength to the researcher's argument, the regression models were nonetheless still significant. Consequently, this lends little evidence for a significant relationship between the variables (Harms \& Credé, 2010; Hur et al., 2011).

Whilst the regression analysis does point to many other factors that also play a role in the prediction of leadership, it shows that EI is gaining a foothold as a predictor of effective leadership, broadly acclaimed as transformational leadership (Cooper \& Sawaf, 1997; Hur et al., 2011). These findings make intuitive sense although they do not clearly suggest that leaders in the petrochemical organisation under study are effective leaders who are self-aware and aware of their followers' sentiments.

Based on the results of the current study and in contrast with similar studies (Avolio et al., 1995; Gardner et al., 2010), it is not indisputably demonstrated that these leaders possess high levels of EI and leverage this EI in order to demonstrate strong transformational leadership behaviours.

Transformational leadership has been shown to be the preferred leadership style under environmental conditions of constant and rapid change (Tucker \& Russell, 2004). For the petrochemical organisation in the study, it can be concluded with some statistical certainty that EI is a predictor of effective transformational leadership style. First of all, Stein and Book (2006) have claimed from the review of the work by Bar-On (2000) that a person's EI is trainable. Leadership research likewise supports the view that transformational leadership is trainable (Barling, Weber \& Kelloway, 1996; Parry \& Sinha, 2005). Focused selection and development of leaders' EI skills might be a recommended mechanism to engage in effective transformational behaviours in this petrochemical organisation.

\section{Limitations}

This research is not without its limitations. Firstly, the sample comprised one business unit within a South Africa petrochemical organisation, which implies that the results cannot be generalised to the entire population. Secondly, as a result of the cross-sectional survey-based research design, causal factors could not be isolated and attributed to the research findings. Thirdly, the sample size may have affected the results of this study. A larger sample may have provided more information regarding the relationships between EI and leadership styles and revealed more insight into demographic differences. Fourthly, in the collection of data the two instruments were not completed at the same time. The MLQ was assessed from an existing database, which may have resulted in weaker correlations. Fifthly, another limitation is the time and cost involved in the data collection from a large sample. Lastly, the use of self-ratings in both questionnaires is a huge limitation, as subjectivity can play a role in the results and therefore the findings of such a study.

\section{Recommendations for future research}

Future studies should aim to include all the business units within the South African petrochemical organisation and to increase the sample size and demographic representation to ensure a more thorough study that can be more easily generalised. Special attention should be paid to ensure a more representative gender distribution. Longitudinal research should be used in future to identify and isolate causal factors, in order to ensure that environmental factors impacting on the data can be isolated and incorporated meaningfully. Data collection for both instruments should be conducted at the same time. Finally, it is suggested that the results of this study should be confirmed by follow-up studies in a variety of contexts in South Africa, because of the apparent absence of specific published works on EI and its purported effects on predicting an effective leadership style. Further research clearly needs to be conducted so as to expand the knowledge about the possible influences or effect EI may have on transformational leadership. For future studies it would be interesting to see differences in leaders' self-perceptions versus those of others and/or to include a multi-rater for the EI as well.

To this end, areas for future investigation might include the impact that the EI of leaders has on the EI of employees and the organisational culture. These areas of study could provide a more complete picture of the emotional dynamics that constitute effective leadership within the South African petrochemical industry. In addition, future research should combine qualitative, quantitative and triangulation methods in order to facilitate a better understanding of the different variables being studied.

\section{Recommendations for organisational practice}

Selected recommendations can be made for the South African petrochemical organisation which might be transferred in part to similar contexts. The organisation should become more aware of the topics of leadership styles and EI, the interrelationship of these two concepts and their impact on the organisation and its employees.

Managers should be trained to explore the positive and negative aspects of the various leadership styles and their 
contextual importance. At the same time, employees should be trained in EI to build an awareness of emotional aspects of leadership competences in order to respond to the growing complexity of (international) human resource management.

The organisation should use the research results to adjust and improve organisational training facilities as well as the process of selection and assessment procedures for evaluating leaders' strengths within the organisation. This could have a significant impact on constructing strategies for developing an organisational leadership culture that is based on EI. Training and mentoring programmes should be adjusted accordingly within the organisation.

Finally, the organisation could use the data to improve managers' strengths and to become aware of developmental areas, whilst at the same time reviewing how executive decisions shape the behaviour of the organisation as a whole. The vision of the organisation could be redefined accordingly.

\section{Conclusion}

Very few differences were found between the EQ and leadership style scores of different demographic groups. In fact, it is only with regard to adaptability that any differences exist between gender and race groups. This is similar to results reported in Van Rooy et al. (2005) with only two subscales, but not total EI that evidenced a statistically-significant effect in favour of Black managers. In addition, it appears that progression through the ranks to senior management in the petrochemical organisation does not seem to hinge on what level of EI or leadership style one possesses.

\section{Acknowledgements Competing interests}

The authors declare that they have no financial or personal relationship(s) which may have inappropriately influenced them in writing this article.

\section{Authors' contributions}

M.P. (University of South Africa) is a Master's student in the Department of Industrial and Organisational Psychology and this article is based on her dissertation of limited scope. R.V. (University of South Africa) was the supervisor of the dissertation and both C.H.M. (University of South Africa) and R.V. contributed with regard to getting the article published.

\section{References}

Antonakis, J., Ashkanasy, N.M., \& Dasborough, M.T. (2009). Does leadership need emotional intelligence? The Leadership Quarterly, 20(2), 247-261. http://dx.doi. org $/ 10.1016 /$ j.leaqua.2009.01.006

Ashkanasy, N.M., \& Daus, C.S. (2005). Rumors of the death of emotional intelligence in organizational behaviour are vastly exaggerated. Journal of Organizational Behaviour, 26(4), 441-452. http://dx.doi.org/10.1002/job.320

Ashkanasy, N.M., \& Tse, B. (2000). Transformational leadership as management of emotion: a conceptual review. In N.M. Ashkanasy, C.E.J. Hartel, \& W.J. Zerbe (Eds), Emotions in the workplace: Research, theory and practice (pp. 221-235) Westport, CT: Quorum Books.

Avolio, B. (1999). Full leadership development: building the vital forces in organizations. Thousand Oaks, CA: Sage.
Avolio, B.J., Bass, B., \& Jung, D.I. (1995). MLQ Multifactor Leadership Questionnaire: technical report. Redwood City, CA: Mind Garden.

Barbuto, J.E. Jr., \& Burbach, M.E. (2006). The emotional intelligence of transformational leaders: a field study of elected officials. The Journal of Social Psychology, 146(1), 51-64. http://dx.doi.org/10.3200/SOCP.146.1.51-64

Barling, J., Slater, F., \& Kelloway, E.K. (2000). Transformational leadership and emotional intelligence: an exploratory study. Leadership \& Organization Development Journal, 21(3), 157-161. http://dx.doi.org/10.1108/01437730010325040

Barling, J., Weber, T., \& Kelloway, E.K. (1996). Effects of transformational leadership training on attitudinal and financial outcomes: A field experiment. Journal of Applied Psychology, 81(6), 827-832. http://dx.doi.org/10.1037/00219010.81 .6 .827

Bar-On, R. (1997). The emotional quotient inventory (EQ-i): technical manual. Toronto: Multi-Health Systems.

Bar-On, R. (2000). Emotional and social intelligence: Insights from the emotional quotient inventory. In R. Bar-On \& J. D. A. Parker (Eds), Handbook of emotional intelligence (pp. 363-388). San Francisco: Jossey-Bass.

Bar-On, R. (2004). The Bar-On emotional quotient inventory (EQ-i): rationale, description, and summary of psychometric properties. In G. Geher (Ed), Measuring emotional intelligence: Common ground and controversy (pp. 115145). Hauppauge, NY: Nova Science.

Bar-On, R. (2006). The Bar-On model of emotional-social intelligence (ESI). Psicothema, 18 Suppl, 13-25.

Bass, B.M. (1985). Leadership: Good, better, best. Organizational Dynamics, 13(3), 26-40. http://dx.doi.org/10.1016/0090-2616(85)90028-2

Bass, B.M. (1990). Bass and Stogdill's handbook of leadership: theory, research and managerial applications (3rd edn.). New York: Free Press.

Bass, B.M. (1997). Concepts of leadership. In R.P. Vecchio (Ed.), Leadership: Understanding the dynamics of power and influence in organizations (pp. 3-23). Notre Dame: University of Notre Dame Press.

Bass, B.M., \& Avolio, B.J. (1994). Introduction. In B.M. Bass, \& B.J. Avolio (Eds.), Improving organisation effectiveness through transformational leadership (pp. 1-9). Thousand Oaks, CA: Sage.

Bass, B.M., \& Avolio, B.J. (1997). Full range leadership development: Manual for the multifactor leadership questionnaire. Palo Alto, CA: Mind Garden.

Bass, B.M., \& Avolio, B.J. (2004). Multifactor leadership questionnaire (3rd edn.). Redwood City, CA: Mind Garden.

Bass, B.M. \& Bass, R. (2008). The Bass handbook of leadership: Theory, research and managerial applications. New York: The Free Press.

Bass, B.M., \& Riggio, R.E. (2006). Transformational leadership (2nd edn.). Mahwah, NJ: Lawrence Erlbaum.

Bass, B.M., Waldman, D.A. Avolio, B.J., \& Bebb, M. (1987). Transformational leaders and the falling dominoes effect. Group Organization Management. 12(1), 73-87. http://dx.doi.org/10.1177/105960118701200106

Boateng, K. (2007). Preparing Africa's future leaders. Conflict Trends, 2, 44-49.

Bono, J.E., \& Ilies, R. (2006). Charisma, positive emotions and mood contagion. The Leadership Quarterly, 17(4), 317-334. http://dx.doi.org/10.1016/j. leaqua.2006.04.008

Booysen, L. (2001). The duality of South African leadership: Afrocentric or Eurocentric. South African Journal of Labour Relations, 25(3\&4), 36-64.

Botha, J. (2002). The relationship between the leadership, internal quality, and customer satisfaction levels of dealerships in a South African motor vehicle organisation. Master's thesis, Rhodes University, Grahamstown.

Brown, F.W., \& Moshavi, D. (2005). Transformational leadership and emotional intelligence: a potential pathway for an increased understanding of interpersonal intelligence: a potential pathway for an increased understanding of interpersonal org/10.1002/job.334

Burns, J.M. (1978). Leadership. New York: Harper \& Row.

Cacioppe, R. (1998). An integrated model and approach for the design of effective leadership programs. Leadership \& Organization Development Journal, 19(1), 44-53. http://dx.doi.org/10.1108/01437739810368820

Cameron, S., Dutton, J., \& Quinn, R. (2003). Positive organizational scholarship: foundations of a new discipline. San Francisco: Berrett-Koehler.

Carless, S.A. (1998). Gender differences in transformational leadership: an examination of superior, leader, and subordinate perspectives. Sex Roles: A Journal of Research, 39(11-12), 887-902. http://dx.doi.org/10.1023/A:1018880706172

Cavallo, K., \& Brienza, D. (2001). Emotional competence and leadership excellence at Johnson \& Johnson: The emotional intelligence and leadership study. Retrieved September 29, 2013 from http://www.eiconsortium.org/reports/ji_ei_study.html

Cavazotte, F., Moreno, V., \& Hickmann, M. (2012). Effects of leader intelligence, personality and emotional intelligence on transformational leadership and managerial performance. The Leadership Quarterly, 23(3), 443-455. http:// dx.doi.org/10.1016/j.leaqua.2011.10.003

Chuang, A., Judge, T.A., \& Liaw, Y.J. (2012). Transformational leadership and customer service: A moderated mediation model of negative affectivity and emotion regulation. European Journal of Work and Organizational Psychology, 21(1), 2856. http://dx.doi.org/10.1080/1359432X.2010.532911

Ciarrochi, J., Hynes, K., \& Crittenden, N. (2005). Can men do better if they try harder: sex and motivational effects on emotional awareness. Cognition and Emotion, 19(1), 133-141. http://dx.doi.org/10.1080/02699930441000102

Clarke, N. (2006). Developing emotional intelligence through workplace learning: findings from a case study in healthcare. Human Resource Development International, 9(4), 447-465. http://dx.doi.org/10.1080/13678860601032585 
Clarke, N. (2010). Emotional intelligence and its relationship to transformational leadership and key project manager competences. Project Management Journal, 41(2), 5-20. http://dx.doi.org/10.1002/pmj.20162

Coetzee, C., \& Schaap, P. (2005). The relationship between leadership behaviour outcomes of leadership and emotional intelligence. SA Journal of Industria Psychology/SA Tydskrif vir Bedryfsielkunde, 31(3), 31-38.

Cohen, J. (1992). A power primer. Psychological Bulletin 112(1), 155-159. http://dx.doi. org/10.1037/0033-2909.112.1.155, PMid:19565683

Cohen, L., Manion, L., \& Morrison, K. (2007). Research methods in education (6th edn.). Abingdon, UK: Routledge.

Cooper, H.M. (1998). Synthesizing research: a guide for literature reviews (3rd edn.) California: Sage.

Cooper, R.K. (1997). Applying emotional intelligence in workplace. Training \& Development, 51(12), 31-38.

Cooper, R.K., \& Sawaf, A. (1997). Executive EQ: emotional intelligence in leadership and organizations. New York: Berkeley.

Den Hartog, D. N., van Muijen, J. J., \& Koopman, P. L. (2011). Transactional versus transformational leadership: An analysis of the MLO Journal of Occupational and Organizational Psychology, 70(1), 19-34. http://dx.doi. org/10.1111/j.2044-8325.1997.tb00628.x

Dibley, J.E. (2009). The relationship between the transformational leadership style of offices and the levels of other followers' work engagement in the South African army. Doctoral dissertation. University of South Africa, Pretoria.

Dulewicz, V. \& Higgs, M. (2003). Assessing leadership styles and organisational context. Journal of Managerial Psychology, 20(2), 105-123. http://dx.doi org/10.1108/02683940510579759

Eagly, A.H., \& Carli, L.L. (2003). The female leadership advantage: an evaluation of the evidence. Leadership Quarterly, 14(6), 807-834. http://dx.doi.org/10.1016/j. leaqua.2003.09.004

Eagly, A.H., \& Johnson, B.T. (1990). Gender and leadership: a meta-analysis. Psychological Bulletin, 108(2), 233-256. http://dx.doi.org/10.1037/0033-2909.108.2.233

Field, A. (2005). Discovering statistics using SPSS (2nd edn.). London: Sage.

Gardner, H. (1983). Can Piaget and Lévi-Strauss be reconciled? New Ideas in Psychology, 1(2), 187-189. http://dx.doi.org/10.1016/0732-118X(83)90015-6

Gardner, L., \& Stough, C. (2002). Examining the relationship between leadership and emotional intelligence in senior level managers. Leadership \& Organization DevelopmentJournal, 23(2),68-78. http://dx.doi.org/10.1108/01437730210419198

Gardner, W.L., Lowe, K.B., Moss, T.W., Mahoney, K.T., \& Cogliser, C.C. (2010). Scholarly leadership of the study of leadership: A review of The Leadership Quarterly's second
decade, 2000-2009. The Leadership Quarterly, 21(6), 922-958. http://dx.doi. org/10.1016/j.leaqua.2010.10.003

Goleman, D. (1995). Emotional intelligence: why it can matter more than IQ. New York: Bantam Books.

Goleman, D. (1998). Working with emotional intelligence. Toronto: Bantam Books.

Goleman, D., Boyatzis, R. \& McKee, A. (2002). Primal leadership: realising the power of emotional intelligence. Boston, MA: Harvard Business School Press.

Harms, P., \& Credé, M. (2010). Emotional intelligence and transformational and transactional leadership: a meta-analysis. Journal of Leadership \& Organizationa Studies, 17(1), 5-17. http://dx.doi.org/10.1177/1548051809350894

Hooijberg, R. Hunt, J.G., \& Dodge, G.E. (1997). Leadership complexity and development of the leaderplex model. Journal of Management, 23(3), 375-408. http://dx.doi. or the $/ 10.1177 / 014920639702300305$

Hunter, B. (2009). Leadership, role clarity and psychological empowerment within a petrochemical organisation. Master's thesis. North West University, Vanderbijlpark.

Hur, Y., van den Berg, P.T., \& Wilderom, C.P.M. (2011). Transformational leadership as a mediator between emotional intelligence and team outcomes. The Leadership Quarterly, 22(4), 591-603. http://dx.doi.org/10.1016/j.leaqua.2011.05.002

Judge, T.A., \& Piccolo, R.F. (2004). Transformational and transactional leadership: a meta-analytic test of their relative validity. Journal of Applied Psychology, 89(5): 755-768. http://dx.doi.org/10.1037/0021-9010.89.5.755, PMid:15506858

Katz, D., \& Kahn, R.L. (1978). The social psychology of organizations (2nd edn.). New York: Wiley.

Laff, M. (2008). Emotional notions. Training \& Development, 62(2), 12-13.

Lam, C.S., \& O'Higgins, E.R. (2012). Enhancing employee outcomes: the interrelated influences of managers' emotional intelligence and leadership style. Leadership \& Organization Development Journal, 33(2), 149-174. http://dx.doi. org/10.1108/01437731211203465

Landy, F.J. (2005). Some historical and scientific issues related to research on emotional intelligence. Journal of Organizational Behavior, 26(4), 411-424. http://dx.doi. org/10.1002/job.317

Leban, W.V. (2003). The relationship between leader behavior and emotional intelligence of the project manager and the success of complex projects. Doctoral dissertation. Benedictine University, Ann Arbor, MI.

Locke, E.A. (2005). Why emotional intelligence is an invalid concept. Journal of Organizational Behavior, 26(4), 425-431. http://dx.doi.org/10.1002/job.318

Lowe, K., Kroeck, K.G., \& Sivasubramaniam, N. (1996). Effectiveness correlates of transformational and transactional leadership: a meta-analytic review of the MLQ
literature. The Leadership Quarterly, 7(3), 385-425. http://dx.doi.org/10.1016/ literature. The Leadership
S1048-9843(96)90027-2

Mayer, J.D., Roberts, R.D., \& Barsade, S.G. (2008). Human abilities: emotiona intelligence. Annual Review of Psychology, 59, 507-536. http://dx.doi.org/10.1146/ annurev.psych.59.103006.093646, PMid:17937602

Mayer, J. D., Salovey, P., \& Caruso, D. R. (2000). Emotional intelligence as Zeitgeist, as personality, and as a mental ability. In R. Bar-On \& J.D.A. Parker (Eds.), The handbook of emotional intelligence: Theory, development, assessment, and the application a home, school and in the workplace (pp. 92-117). San Francisco, CA: Jossey-Bass.
McCallum, M., \& Piper, W.E. (2000). Psychological mindedness and emotional intelligence. In R. Bar-On \& J.D.A. Parker (Eds.), The handbook of emotional intelligence: Theory, development, assessment, and the application at home, school intelligence: Theory, development, assessment, and the application
and in the workplace (pp. 118-135). San Francisco: Jossey-Bass.

Ndlovu, N., \& Parumasur, S.B. (2005). The perceived impact of downsizing and organisational transformation on survivors. SA Journal of Industrial Psychology/SA Tydskrif vir Bedryfsielkunde, 31(2), 14-21.

Northouse, PG. (2012). Leadership: theory and practice (6th edn.). New York: Sage. Nunnally, C.J., \& Bernstein, I.H. (2010). Psychometric theory. New York: McGraw-Hill. Pallant, J. (2001). SPSS survival manual. Milton Keynes: Open University Press.

Palmer, B.R., Gardner, L. \& Stough, C. (2003). The relationship between emotional intelligence, personality and effective leadership. Paper presented at 5 th Australian Industrial \& Organizational Psychology Conference, Melbourne.

Parry, K.W., \& Sinha, P.N. (2005). Researching the trainability of transformational organizational leadership. Human Resource Development International, 8(2), 165organizational leadership. Human Resource Developm
183. http://dx.doi.org/10.1080/13678860500100186

Petrides, K.V. (2010). Trait emotional intelligence theory. Industrial and Organizationa Psychology, 3, 136-139. http://dx.doi.org/10.1111/j.1754-9434.2010.01213.x

Petrides, K.V., Frederickson, N., \& Furnham, A. (2004). The role of trait emotional intelligence in academic performance and deviant behavior at school. Personality and Individual Differences, 36(2), 277-293. http://dx.doi.org/10.1016/S01918869(03)00084-9

Piel, M.A. (2008). Emotional intelligence and critical thinking relationships to transformational leadership. Doctoral dissertation. University of Phoenix, Arizona.

Ramesar, S., Koortzen, P., \& Oosthuizen, R.M. (2009). The relationship between emotional intelligence and stress management. SA Journal of Industrial Psychology/ SA Tydskrif vir Bedryfsielkunde, 35(1), 39-48.

Riggio, R.E., \& Reichard, R.J. (2008). The emotional and social intelligences of effective leadership: An emotional and social skill approach. Journal of Managerial Psychology, 23(2), 169-185. http://dx.doi.org/10.1108/02683940810850808

Robbins, S.P., Judge, T.A., Odendaal, A., \& Roodt, A. (2009). Organisational behaviour: global and Southern African perspectives. Cape Town: Pearson.

Roberts, R.D., Zeidner, M., \& Matthews, G. (2001). Does emotional intelligence meet traditional standards for an intelligence? Some new data and conclusions. Emotion 1(3), 196-231. http://dx.doi.org/10.1037/1528-3542.1.3.196, PMid:12934681

Rost, J.C. (1991). Leadership for the twenty-first century. New York: Greenwood.

Salovey, P., \& Mayer, J.D. (1990). Emotional intelligence. Imagination, Cognition \& Personality, 9(3), 185-211. http://dx.doi.org/10.2190/DUGG-P24E-52WK-6CDG

Schlechter, A.F., \& Strauss, J.J. (2008). Leader emotional intelligence, transformational leadership, trust and team commitment: Testing a model within a team context. SA Journal of Industrial Psychology/SA Tydskrif vir Bedryfsielkunde, 34(1), 42-53.

Snodgrass, J., \& Shachar, M. (2008). Faculty perceptions of occupational therapy program directors' leadership styles and outcomes of leadership. Journal of Allied Health, 37(4), 225-235.

SPSS Inc. (2010). SPSS Statistics for Windows, Version 18.0. Chicago: SPSS Inc.

Stander, M. (2007). Psychological empowerment, job security and wellness of employees in selected organisations. Doctoral dissertation. North West University, Vanderbijlpark.

Stein, S.J., \& Book, H.E. (2006). The EQ Edge: emotional intelligence and your success. Mississauga, Ontario: John Wiley.

Stough, C., Saklofske, D.H., \& Parker, J.D. (2009). A brief analysis of 20 years of emotional intelligence: an introduction to assessing emotional intelligence: theory, research, and applications. Assessing Emotional Intelligence: The Springer Series on Human Exceptionality, 3-8. http://dx.doi.org/10.1007/978-0-387-88370-0_1

Thomas, A., \& Bendixen, M. (2000). The management implications of ethnicity in South Africa. Journal of International Business Studies, 31(3), 507-519. http://dx.doi. org/10.1057/palgrave.jibs.8490919

Tredoux, C., \& Durrheim, K. (2006). Numbers, hypotheses and conclusions: a course in statistics for the social sciences. Cape Town: UCT Press. PMid:16850254

Tucker, B.A., \& Russell, R.F. (2004). The influence of the transformational leader Journal of Leadership \& Organizational Studies, 10(4), 103-111. http://dx.doi. Journal of Leadership \& Organization
org/10.1177/107179190401000408

Van Rooy, D.L., Alonso, A., \& Viswesvaran, C. (2005). Group differences in emotional intelligence scores: theoretical and practical implications. Personality and Individual Differences, 38(3), 689-700. http://dx.doi.org/10.1016/j.paid.2004.05.023

Van Rooy, D.L., Dilchert, S., Viswesvaran, C., \& Ones, D.S. (2006). Multiplying intelligences: are general, emotional, and practical intelligences equal? In K.R. Murphy (Ed.). The case against emotional intelligence: what are the problems and how can they be fixed? (pp. 235-262). Mahwah, NJ: Erlbaum.

Wasylyshyn, K.M. (2004). Emotional competence: preliminary results of a coaching program commissioned by Rohm and Haas. Human Resource Planning, 27(4), 7.

Williams, J.M. (2011). Differences in the correlation between locus of control and emotional intelligence among job corps versus same aged students in vocational training programs. Doctoral dissertation. Capella University, Minneapolis, MN.

Yamminaro, F.J., \& Dubinsky, A.J. (1994). Transformational leadership theory: using levels of work to determine boundary conditions. Personnel Psychology, 47(4), 787-811. http://dx.doi.org/10.1111/j.1744-6570.1994.tb01576.x

Zaccaro, S.J. (2001). The nature of executive leadership: A conceptual and empirical analysis of success. Washington, DC: American Psychological Association. http:// dx.doi.org/10.1037/10398-000

Zagoršek, H., Dimovski, V., \& Škerlavaj, M. (2009). Transactional and transformational leadership impacts on organizational learning. Journal for East European Management Studies, 14(2), 144-165. 